\title{
Effectiveness of Ginseng Berry Marc Extract for Skin Improvement
}

\author{
Hyeon-Suk Kim \\ Department of Beauty Design, Wonkwang University, Iksan-si, Jeollabuk-do, Korea
}

Corresponding author: Hyeon-Suk Kim, Department of Beauty Design, Wonkwang University, 460 Iksandae-ro, Iksan-si, Jeollabuk-do 54538, Korea

Tel.: +82638506649

Fax: +82638506666

Email: kkenns@naver.com

\section{Received February 09, 2021}

Revised March 10, 2021

Accepted March 11, 2021

Published March 30, 2021

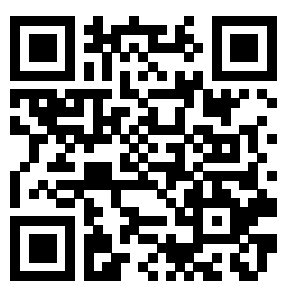

\begin{abstract}
Purpose: This study identifies the possibility of ginseng berry marc as a cosmetic material for skin improvement through a physiological activation experiment. Methods: The measurement of the total polyphenol and flavonoid content, evaluation of antioxidants through DPPH radical scavenging activity, and cell viability ratio of $70 \%$ ethanol extract of ginseng berry marc extracts were conducted. To access the anti-inflammatory effects, NO generative inhibitory measurements and cell regeneration by cell migration assessment were investigated. Results: The total polyphenol content was $335 \pm 12.3 \mathrm{mg} / \mathrm{g}$, and the total flavonoid content was $79 \pm 3.2 \mathrm{mg} / \mathrm{g}$. DPPH radical scavenging activity also showed a concentrationdependent increase as the concentration increased to $37.73 \% \pm 2.47 \%$ at $0.25 \mathrm{mg} /$ $\mathrm{mL}, 49.33 \% \pm 0.66 \%$ at $0.5 \mathrm{mg} / \mathrm{mL}, 73.56 \% \pm 3.56 \%$ at $0.75 \mathrm{mg} / \mathrm{mL}$, and $80.51 \% \pm$ $0.51 \%$ at $0.9 \mathrm{mg} / \mathrm{mL}$. The cell viability evaluation (MTT assay) was $93.33 \% \pm 1.88 \%$ at $0.25 \mathrm{mg} / \mathrm{mL}, 90.66 \% \pm 1.24 \%$ at $0.5 \mathrm{mg} / \mathrm{mL}, 88.66 \% \pm 1.69 \%$ at $0.75 \mathrm{mg} / \mathrm{mL}$, and $83.1 \% \pm 0.94 \%$ at $0.9 \mathrm{mg} / \mathrm{mL}$. At concentrations of 0.25 and $0.5 \mathrm{mg} / \mathrm{mL}$, the cell survival rate is greater than $90 \%$, and the lowest survival rate is greater than $80 \%$, indicating that there is no problem with the safety of cytotoxicity. The antiinflammatory evaluation showed that NO decreased as the concentration increased with $31.76 \pm 0.52 \mu \mathrm{M}$ at $0.25 \mathrm{mg} / \mathrm{mL}, 21.76 \pm 0.52 \mu \mathrm{M}$ at $0.5 \mathrm{mg} / \mathrm{mL}, 10.86 \pm$ $0.47 \mu \mathrm{M}$ at $0.75 \mathrm{mg} / \mathrm{mL}$, and $9.76 \pm 0.28 \mu \mathrm{M}$ at $0.9 \mathrm{mg} / \mathrm{mL}$. According to the comparison of cell movement and recovery conditions by concentration, the higher the concentration $2.5 \mathrm{mg} / \mathrm{mL}, 5 \mathrm{mg} / \mathrm{mL}$, and $10 \mathrm{mg} / \mathrm{mL}$, the faster space is filled, which can help the skin recover and regenerate. Conclusion: Eco-friendly natural ingredients can be obtained through upcycling of ginseng berry marc, which can be used as an effective skin-improving cosmetics ingredient through more studies.
\end{abstract}

Keywords: Ginseng berry marc, Skin improvement, Antioxidant, Anti-inflammatory, Skin regeneration

\section{Introduction}

Recently, the development of eco-friendly and natural cosmetics materials has been steadily growing in the cosmetics industry to improve skin worldwide. With the development of biotechnology, the demand for functional cosmetics containing natural ingredients is increasing. Consumers seek natural ingredient cosmetics to maintain human body protection and homeostasis from harmful environmental factors. (Ham et al., 2018).
Their so-called good values and consumption are seen as pursuing eco-friendly materials, and cosmetics materials of natural ingredients are especially recognized for their value. As a result, the fruits of plants and their extracts are steadily used as natural materials for cosmetics produced in Korea, and research on them is also continuously conducted. According to the results of the previous study, six berries types, including chokeberry, blueberry, raspberry, blackberry, mulberry, and cherry, were evaluated that the antioxidant and anti-inflammatory effects 
were excellent, and all efficacy was increased when they were mixed (Kim \& Kim, 2020). Furthermore, the prior studies' results on antioxidants (Song et al., 2014), anti-inflammatory (Lee et al., 2014), and anti-aging (Jeon et al., 2011) effects proved that ginseng (Panax ginseng C.A. Meyer) berry extract is a safe nontoxic material. This berry type can be used as a natural functional cosmetics material with excellent antioxidant activity and anti-inflammatory efficacy (Kim \& Ko, 2020). Another study has reported that ginseng berry has anti-cancer, anti-allergic, and anti-photo-aging effects, and skin aging improvement (Yeom et al., 2010).

The ginseng berry marc is the leftover scraps after the use of ginseng berry. However, unlike various studies on ginseng berry, little research has been conducted on ginseng berry marc. In a previous study on ginseng marcs, it was found that fat-soluble ingredients such as sulfuric acid and anti-cancer activity remained similar to ginseng and can be used as an effective ingredient by its physiological active composition (In et al., 2014). Ginseng berry marc is a natural material that can be used in beauty skin products' development, environmental awareness, and sustainable practices in Korea.

Therefore, this study evaluates the physiological activity (cell viability ratio, antioxidant, anti-inflammatory, and cell regeneration effect) of ginseng berry marc to identify the possibility of its use as a cosmetic material for skin improvement.

\section{Methods}

\section{Experimental material}

Ginseng berry marc used in this experiment, grown in Gimje-si, Jeollabuk-do, and dried under hot-air (Agricultural dryer; HDG-230T, Hyundai Enertec Co., Ltd., Korea), was gained as a byproduct after extraction of ginseng berry oil. 10\% of ginseng berry marc were immersed in $70 \%$ ethanol solution, and the effective ingredient was extracted at $25^{\circ} \mathrm{C}$ for $6 \mathrm{~h}$. Afterward, it was operated 20 min of the centrifuge (CS150NX; Hitachi Ltd. Tokyo, Japan) at $4{ }^{\circ} \mathrm{C}$ to $4000 \mathrm{rpm}$, separated the upper layer solution, and filtered (ADVANTEC Co. Ltd, Japan) three times. Then, it was concentrated using a pressure reduction concentrator (Evaporator; Tokyo Rikakikai co. Ltd., Japan), frozen dry, and made the extract powder of ginseng berry marc as experimental material.

\section{Antioxidant activity}

1) Total polyphenol Content Measurement

$1 \mathrm{~mL}$ of $1 \mathrm{~N}$ Folin-Ciocalteu agent was applied to a solution prepared with a concentration of $1 \mathrm{mg} / \mathrm{mL}$ of ginseng berry marc, after $5 \mathrm{~min}$ reaction and applying $1 \mathrm{~mL}$ of a $10 \% \mathrm{Na}_{2} \mathrm{CO}_{3}$ solution, $1 \mathrm{~h}$ retaining the mixture at room temperature, and finally measured absorbance at $700 \mathrm{~nm}$ using a spectrophotometer (UV-2450; Shimadzu Co., Japan). The total polyphenol content was calculated from the standard curve obtained using Gallic acid (GAE; Sigma-Aldrich, USA).

\section{2) Total flavonoid content}

$2 \mathrm{~mL}$ of Di-ethylene glycol (Sigma-Aldrich) and $0.02 \mathrm{~mL}$ of $1 \mathrm{~N} \mathrm{NaOH}$ (Sigma-Aldrich) were added to the solution prepared with a concentration of $200 \mu \mathrm{g} / \mathrm{mL}$ of ginseng berry marc. The absorbance was measured at $420 \mathrm{~nm}$ using a spectrophotometer (UV-2450; Shimadzu Co.) after retaining for $37^{\circ} \mathrm{C}$ and $1 \mathrm{~h}$. The total flavonoid content was measured using quercetin (SigmaAldrich) as a standard substance by creating a correction curve.

\section{3) $\mathrm{DPPH}$ radical scavenging activity}

For antioxidant measurements, 2,2-Diphenyl-1picrylhydrazyl (DPPH; Sigma-Aldrich) radical scavenging activity was performed using the Blois method (Blois, 1958). Added $1 \mathrm{~mL}$ of $0.2 \mathrm{mM} \mathrm{DPPH}$ solution (Sigma-Aldrich) to 2 $\mathrm{mL}$ of the sample and measured absorbance at $517 \mathrm{~nm}$ using a spectrophotometer (UV-2450; Shimadzu Co.) after 30 min in the darkroom. The radical scavenging activity was calculated using the following formula.

$\mathrm{DPPH}$ radical scavenging activity $(\%)=[1-(\mathrm{B} / \mathrm{A})] \times 100$

A: Absorbance of controls with only DPPH solution

B: Absorbance of DPPH solution with the sample solution

\section{Cell viability evaluation (MTT assay)}

A cytotoxicity test, 3-(4,5-dimethylthiazol-2-yl)-2,5diphenyl tetrazolium bromide (MTT) assay, was performed on ginseng berry marc extracts. For the cytotoxicity test, the concentration of the RAW 264.7 cell specimen was arranged and treated at $0.25 \mathrm{mg} / \mathrm{mL}, 0.5 \mathrm{mg} / \mathrm{mL}, 0.75 \mathrm{mg} / \mathrm{mL}$, and 0.9 $\mathrm{mg} / \mathrm{mL}$. Then, 96-well plates were injected with $1 \times 10^{4}$ cells/ $\mathrm{mL}$ each and cultured for $24 \mathrm{~h}$. After incubation, each well was treated with the diluted extract and incubated for $24 \mathrm{~h}$. After removing $100 \mu \mathrm{L}$ of cultured fluid, $10 \mu \mathrm{L}$ of MTT solution was added to each well and reacted for $4 \mathrm{~h}$ at $37^{\circ} \mathrm{C}$ and $5 \%$ 
$\mathrm{CO}_{2}$ incubators. The MTT solution was removed, and $200 \mu \mathrm{L}$ dimethyl sulfoxide (DMSO; Sigma-Aldrich) was used into each to dissolve the formazan crystals to measure $570 \mathrm{~nm}$ absorbance with ELISA plate reader (Bio Tec Ex800, USA). The cell viability ratio was calculated as a percentage (\%).

\section{Anti-inflammatory evaluation (NO assay)}

For conducting the anti-inflammatory assessment, RAW 264.7 cells (mouse monocyte macrophages) from the Korea Cell State Bank Biological Resource Center were used to measure the production inhibitory activity of nitric oxide (NO). Raw 264.7 cells were injected into each and incubated at a concentration of $3 \times 10^{4}$ cells/well for $24 \mathrm{~h}$ at incubator $\left(37^{\circ} \mathrm{C}, 5 \% \mathrm{CO}_{2}\right)$. Extracts were treated in each well with various concentrations of 0.25 $\mathrm{mg} / \mathrm{mL}, 0.5 \mathrm{mg} / \mathrm{mL}, 0.75 \mathrm{mg} / \mathrm{mL}$, and $0.9 \mathrm{mg} / \mathrm{mL}$. The equivalent amounts of LPS $1 \mu \mathrm{L} / \mathrm{mL}$ were treated and incubated at incubator $\left(37^{\circ} \mathrm{C}, 5 \% \mathrm{CO}_{2}\right)$ for $24 \mathrm{~h}$. After adding $100 \mu \mathrm{L}$ of cultured fluid and equivalent greasing reagent, reacting for 10 min, the absorbance was measured at $540 \mathrm{~nm}$ with the ELISA plate reader (BioTec Ex800, USA). Standard was quantified using $\mathrm{NaNO}_{2}$.

\section{Cell regeneration evaluation}

The in vitro scratch assay (Liang et al., 2007) method was used to test cell regeneration of ginseng berry marc extracts using HaCaT cells. These cells were injected into each at a concentration of $5 \times 10^{4}$ cells $/ \mathrm{mL}$ at 48 well plates. They were incubated for $24 \mathrm{~h}$ in a cell culture machine $\left(37^{\circ} \mathrm{C}, 5 \% \mathrm{CO}_{2}\right)$ and were scratched using a p200 pipette tip in the cell fault. $100 \mu \mathrm{L}$ of the elution of each concentration $(2.5 \mathrm{mg} / \mathrm{mL}, 5 \mathrm{mg} / \mathrm{mL}, 10$ $\mathrm{mg} / \mathrm{mL}$ ) of ginseng berry marc was treated and incubated for $24 \mathrm{~h}$. The status of cell migration and recovery was compared through an Inverted microscope (CKX53; Olympus-Scope, Japan) by different extract concentrations.

\section{Statistics processing}

The experimental results were analyzed with SPSS statistics 24 (IBM, USA), which obtained the mean and standard deviation. Student's t-test was conducted and Post-test for

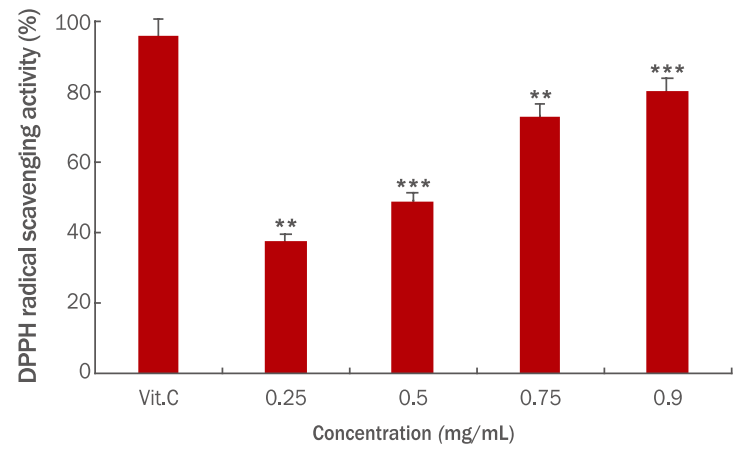

Figure 1. DPPH radical scavenging activity of ginseng berry marc ethanol extract.

DPPH radical scavenging analysis was performed to investigate. The antioxidant effects of ginseng berry marc at varying concentration levels of $0.25 \mathrm{mg} / \mathrm{mL}, 0.5 \mathrm{mg} / \mathrm{mL}, 0.75 \mathrm{mg} / \mathrm{mL}$, $0.9 \mathrm{mg} / \mathrm{mL}$. Each value presents the mean \pm standard deviation $(n=3)$. Statistically significant differences are marked with an asterisk ( $\left.{ }^{*} p<0.05,{ }^{* *} p<0.01,{ }^{* * *} p<0.001\right)$.

the mean difference was determined to be significant at $5 \%$ of $p$-value $(p<0.05)$.

\section{Results and Discussion}

\section{Total polyphenol and flavonoid content}

This study examined the antioxidant efficacy by measuring the total polyphenol and flavonoid content present in ethanol extract of ginseng berry marc. The result shows that the total polyphenol content of ginseng berry marc extract was $335 \pm 12.3$ $\mathrm{mg} / \mathrm{g}$, and the total flavonoid content was $79 \pm 3.2 \mathrm{mg} / \mathrm{g}$ (Table 1). These results are higher than that of polyphenols (44.1-178.3 $\mathrm{mg}$ GAE/g dw) and flavonoids (4.1-40.3 mg QE/g dw) indicated in previous studies of fruit skin antioxidant activity (Lee et al., 2012).

\section{DPPH radical scavenging activity}

The DPPH measurement method used to check the antioxidant of ginseng berry marc extract is a method to determine the DPPH radical scavenging activity. The control

Table 1. Total polyphenol and flavonoid contents of ethanol extracts of ginseng berry marc

\begin{tabular}{lcc}
\hline & Total polyphenol contents (GAE mg/g) & Total flavonoid contents (TA/100g) \\
Ginseng berry marc & $335 \pm 12.3$ & $79 \pm 3.2$ \\
\hline
\end{tabular}

Mean $\pm S D,(n=3)$. 


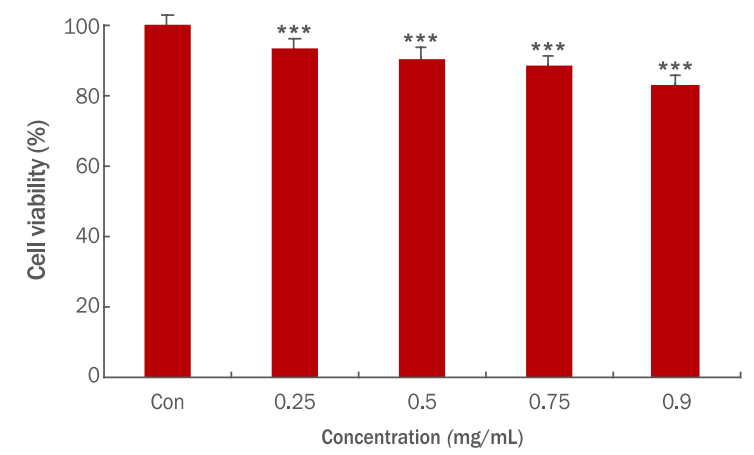

Figure 2. Effect of ethanol extracts on ginseng berry marc on cell viability of RAW 264.7 cells.

RAW 264.7 cells were treated with ethanol extracts on ginseng berry marc at varying concentration levels $0.25 \mathrm{mg} / \mathrm{mL}, 0.5 \mathrm{mg} /$ $\mathrm{mL}, 0.75 \mathrm{mg} / \mathrm{mL}, 0.9 \mathrm{mg} / \mathrm{mL}$. The values are expressed as the means \pm standard deviation of three individual experiments. Statistically significant differences are marked with an asterisk $\left({ }^{* * *} p<0.001\right)$.

group handled with ascorbic acid $1 \mathrm{mg} / \mathrm{mL}$, seen in Figure 1 , had a DPPH radical scavenging activity of $96.2 \%$. The concentration of ethanol extract from ginseng berry marc shows $37.73 \% \pm 2.47 \%$ at $0.25 \mathrm{mg} / \mathrm{mL}, 49.33 \% \pm 0.66 \%$ at $0.5 \mathrm{mg} / \mathrm{mL}$, $73.56 \% \pm 3.56 \%$ at $0.75 \mathrm{mg} / \mathrm{mL}$, and $80.51 \% \pm 0.51 \%$ at $0.9 \mathrm{mg} /$ $\mathrm{mL}$. These results show a concentration-dependent increase as the concentration increased and high antioxidant activity. As reported in previous studies, the hexane extract of ginseng marc obtained from ginseng is a byproduct with approximately the same level of antioxidant and anti-cancer activity as its efficacy in ginseng (In et al., 2014). The high DPPH radical scavenging activity indicates that ginseng berry marc extract has an antioxidant effect in skin improvement (Figure 1).

\section{Cell viability evaluation (MTT assay)}

The results of the test to determine the cell viability ratio of ginseng berry marc extract are presented in Figure 2. When evaluated in concentration ranges of $0.25 \mathrm{mg} / \mathrm{mL}, 0.5 \mathrm{mg} / \mathrm{mL}$, $0.75 \mathrm{mg} / \mathrm{mL}, 0.9 \mathrm{mg} / \mathrm{mL}$, the cell viability ratio was $93.33 \% \pm$ $1.88 \%, 90.66 \% \pm 1.24 \%, 88.66 \% \pm 1.69 \%$, and $83.10 \% \pm 0.94 \%$, respectively. The cell survival tended to decrease slightly as ginseng berry mark extracts went from concentration of 0.25 $\mathrm{mg} / \mathrm{mL}$ to $0.9 \mathrm{mg} / \mathrm{mL}$. However, at concentrations of 0.25 and $0.5 \mathrm{mg} / \mathrm{mL}$, the cell survival rate is greater than $90 \%$, and the lowest survival rate is greater than $80 \%$, indicating that there is no problem with the safety of cytotoxicity.

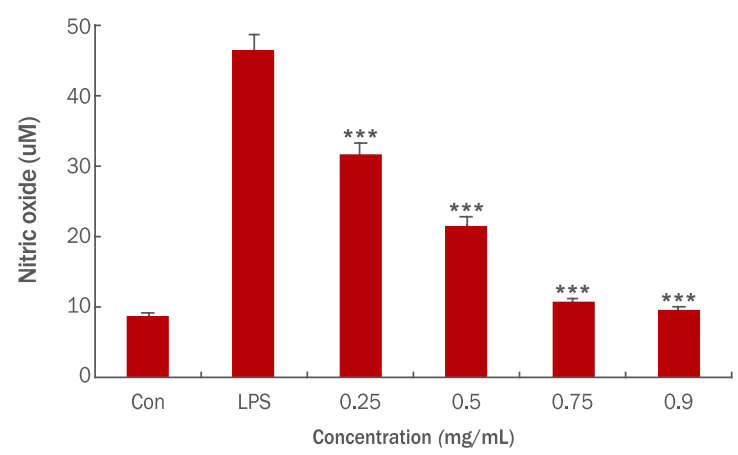

Figure 3. Effects of ethanol extracts on ginseng berry marc on LPS-induced nitric oxide production RAW 264.7 cells.

RAW 264.7 cells were treated at the indicated concentrations of ginseng berry marc extracts and treated with LPS $(1 \mathrm{\mu g} /$ $\mathrm{mL}$ ). After $24 \mathrm{~h}$ of incubation, the amounts of nitric oxide were measured by Griess reaction assay. Results are represented as mean \pm standard deviation. Statistically significant differences are marked with an asterisk $\left.{ }^{* * *} p<0.001\right)$.

\section{Anti-inflammatory evaluation (NO assay)}

An experiment nitrite oxide (NO) was conducted to verify the anti-inflammatory efficacy of ginseng berry marc extracts, and the measurement of the control group was $8.83 \pm 0.46 \mu \mathrm{M}$. The amount of NO produced by LPS at a concentration of $46.67 \pm 1.54$ $\mu \mathrm{M}$ shows that the concentration of ginseng berry marc extract decreased, respectively, $31.76 \pm 0.52 \mu \mathrm{M}$ at $0.25 \mathrm{mg} / \mathrm{mL}, 21.76$ $\pm 0.52 \mu \mathrm{M}$ at $0.5 \mathrm{mg} / \mathrm{mL}, 10.86 \pm 0.47 \mu \mathrm{M}$ at $0.75 \mathrm{mg} / \mathrm{mL}$, and $9.76 \pm 0.28 \mu \mathrm{M}$ at $0.9 \mathrm{mg} / \mathrm{mL}$. As the concentration of ginseng berry marc extract increased, NO production decreased (Figure 3). So, ginseng berry extract was found to have an antiinflammatory effect and relieve inflammation. Prior research revealed that the ingredients of polyphenolic substances at the ground level of ginseng fruits have a major effect on antiinflammatory efficacy rather than saponin, also contained in ginseng berry (Lee et al., 2014). Therefore, ginseng berry marc extract has an anti-inflammatory effect, being an effective cosmetic material effective in improving inflammatory skin.

\section{Cell regeneration evaluation}

To determine how ginseng berry marc extract affects skin improvement, HaCaT cells were injected into each and cultured, treated the extract by concentration $(2.5 \mathrm{mg} / \mathrm{mL}, 5 \mathrm{mg} / \mathrm{mL}$, and $10 \mathrm{mg} / \mathrm{mL}$ ), and checked whether cell migration was active in the space created. Through an inverted microscope (CKX53; Olympus-Scope), cell movement and recovery conditions were 


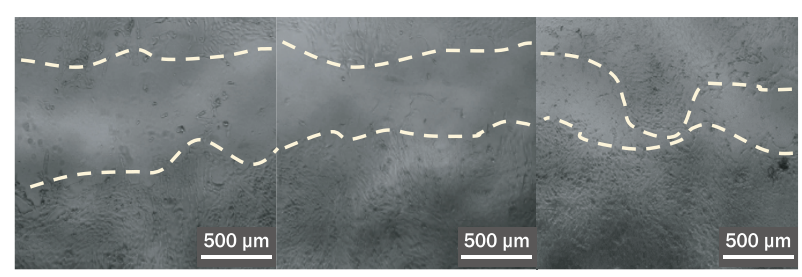

$2.5 \mathrm{mg} / \mathrm{mL}$

$5 \mathrm{mg} / \mathrm{mL}$

$10 \mathrm{mg} / \mathrm{mL}$

Figure 4. Effect of ginseng berry marc ethanol extracts on cell migration.

$\mathrm{HaCaT}$ cells were concentrated on 48 well plates at a concentration of $5 \times 10^{4}$ cells $/ \mathrm{mL}$, stabilized at a cell culture medium $\left(37^{\circ} \mathrm{C}, 5 \% \mathrm{CO}_{2}\right)$, scratched the cell layer for $24 \mathrm{~h}$ to create space.

compared with different extract concentrations. The results (Figure 4) indicated that the higher the concentration, the faster space is filled, and the narrower the area can be. Prior studies of ginseng berry extracts have shown efficacy in promoting the production of hyaluronic acid, which is highly involved in water retention, intercellular spacing, cell division, and differentiation movement in the skin (Yeom et al., 2010). In addition, this result indicates that it is a material that can help the skin recover and regenerate.

\section{Conclusion}

The present study examined the total polyphenols and flavonoids content to determine the physiological activity (antioxidant, anti-inflammatory, and cell regeneration) of ginseng berry marc extracts. In addition, were conducted several experiments, such as antioxidant activity (DPPH), cell viability evaluation (MTT assay), anti-inflammatory evaluation (NO assay), and cell regeneration evaluation to determine whether ginseng berry marc extracts improve the skin.

As a result, the total polyphenol content of ginseng berry marc was $335 \pm 12.3 \mathrm{mg} / \mathrm{g}$, and the total flavonoid content was $79 \pm 3.2 \mathrm{mg} / \mathrm{g}$. The antioxidant effect (DPPH radical scavenging activity) also showed a concentration-dependent increase as the concentration increased to $37.73 \% \pm 2.47 \%$ at $0.25 \mathrm{mg} /$ $\mathrm{mL}, 49.33 \% \pm 0.66 \%$ at $0.5 \mathrm{mg} / \mathrm{mL}, 73.56 \% \pm 3.56 \%$ at 0.75 $\mathrm{mg} / \mathrm{mL}$, and $80.51 \% \pm 0.51 \%$ at $0.9 \mathrm{mg} / \mathrm{mL}$. The cell viability evaluation (MTT assay) was $93.33 \% \pm 1.88 \%$ at $0.25 \mathrm{mg} / \mathrm{mL}$, $90.66 \% \pm 1.24 \%$ at $0.5 \mathrm{mg} / \mathrm{mL}, 88.66 \% \pm 1.69 \%$ at $0.75 \mathrm{mg} / \mathrm{mL}$ and $83.1 \% \pm 0.94 \%$ at $0.9 \mathrm{mg} / \mathrm{mL}$. At concentrations of 0.25 and $0.5 \mathrm{mg} / \mathrm{mL}$, the cell survival rate is greater than $90 \%$, and the lowest survival rate is greater than $80 \%$, indicating that there is no problem with the safety of cytotoxicity. The antiinflammatory evaluation (NO assay) showed that NO decreased as the concentration increased with $31.76 \pm 0.52 \mu \mathrm{M}$ at 0.25 $\mathrm{mg} / \mathrm{mL}, 21.76 \pm 0.52 \mu \mathrm{M}$ at $0.5 \mathrm{mg} / \mathrm{mL}, 10.86 \pm 0.47 \mu \mathrm{M}$ at 0.75 $\mathrm{mg} / \mathrm{mL}$, and $9.76 \pm 0.28 \mu \mathrm{M}$ at $0.9 \mathrm{mg} / \mathrm{mL}$. According to the extract concentration comparison of cell movement and recovery conditions, the higher the concentration, the faster space is filled, which can help the skin recover and regenerate.

The results of the physiological activation experiments show that ginseng berry marc has effectiveness in antioxidant, anti-inflammatory, and cell regeneration. In the near future, through more studies, eco-friendly natural ingredients can be obtained through upcycling, where these discarded natural byproducts can be used as an effective cosmetic ingredient for skin-improving.

\section{Author's contribution}

HSK designed and analyzed all experimental surveys. HSK wrote the manuscripts.

\section{Author details}

Hyeon-Suk Kim (Lecturer), Department of Beauty Design, Wonkwang University, 460 Iksandae-ro, Iksan-si, Jeollabuk-do 54538, Korea.

\section{References}

Blois MS. Antioxidant determination by the use of a stable free radical. Nature, 181: 1199-1200, 1958.

Ham HN, Abinash Chandra Shrestha, Kim JE, Lee TB, Yoo BW, Kim MS, Kim KS, Cha JS, Lee YM, Kim JY, Leem JY. Simultaneous analysis of the compounds of natural cosmetic resources containing Chrysanthemum zawadskii, Perilla frutescens, Rosa multiflora and their anti-oxidative activity. Korean Journal of Pharmacognosy, 49: 312-321, 2018.

In MJ, Chae HJ, Kim DC. In vitro antioxidant and anticancer 
potential of $n$-hexane extract from ginseng marc. Journal of Applied Biological Chemistry, 57: 247-250, 2014.

Jeon JM, Choi SK, Kim YJ, Jang SJ, Cheon JW, Lee HS. Antioxidant and antiaging effect of ginseng berry extract fermented by lactic acid bacteria. Journal of the Society of Cosmetic Scientists of Korea, 37: 75-81, 2011.

Kim HS, Ko KS. Antioxidant and anti-inflammatory effects of ginseng berry ethanol extracts as a cosmetic ingredient. Asian Journal of Beauty and Cosmetology, 18: 389-394; 2020.

Kim YR, Kim AJ. Evaluation of the biological activities of berries as an inner beauty ingredient. Asian Journal of Beauty and Cosmetology, 18: 375-387, 2020.

Lee KS, Kim GH, Seong BJ, Kim SI, Han SH, Lee SS, Yang H, Yoo YC. Anti-inflammatory activity of solvent fractions from ginseng berry extract in LPS-induced RAW264.7 cells. Korean Journal of Medicinal Crop Science, 22: 449-456, 2014.

Lee MY, Yoo MS, Whang YJ, Jin YJ, Hong MH, Pyo YH. Vitamin $\mathrm{C}$, total polyphenol, flavonoid contents and antioxidant capacity of several fruit peels. Korean Journal of Food Science and Technology, 44: 540-544, 2012.

Liang CC, Park AY, Guan JL. In vitro scratch assay: a convenient and inexpensive method for analysis of cell migration in vitro. Nature Protocols, 2: 329-333, 2007.

Song JH, Shon MS, Kim HO, Kim JS, Kim ES, Kim GN. Antioxidant activity of oil extracted from ginseng seed. Asian Journal of Beauty and Cosmetology, 12: 235-240, 2014.

Yeom MH, Lee JY, Kim JS, Park CW, Kim DH, Kim HK. The anti-aging effects of Korean ginseng berry in the skin. Korean Journal of Pharmacognosy, 41: 26-30, 2010. 


\section{국문초록}

\section{피부개선을 위한 인삼열매박 추출물의 효능}

김현숙

원광대학교 뷰티디자인학부, 전라북도 익산시, 한국

목적: 본 연구에서는 인삼열매박의 피부개선을 위한 화장품 소재로의 활용 가능성을 규명하고자 생리활성을 실험을 진행하였다. 방 법: 인삼열매박 $70 \%$ 에탄올 추출물의 총 폴리페놀, 플라보노이드 함량과 DPPH 소거활성 평가를 통한 항산화, 세포 생존율(MTT assay) 평가를 하였다. 또한 $\mathrm{NO}$ 생성 저해 측정을 통해 항염 효과를 알아보고 세포이동률 평가를 통해 세포 재생에 관하여 알아보 았다. 결과: 총 폴리페놀 함량은 $335 \pm 12.3 \mathrm{mg} / \mathrm{g}$ 로 나타났으며, 총 플라보노이드 함량은 $79 \pm 3.2 \mathrm{mg} / \mathrm{g}$ 로 나타났다. DPPH free radical 소거능은 인삼열매박 추출물 농도 $0.25 \mathrm{mg} / \mathrm{mL}$ 에서 $37.73 \% \pm 2.47 \%, 0.5 \mathrm{mg} / \mathrm{mL}$ 에서 $49.33 \% \pm 0.66 \%, 0.75 \mathrm{mg} / \mathrm{mL}$ 에 서 $73.56 \% \pm 3.56 \%, 0.9 \mathrm{mg} / \mathrm{mL}$ 에서 $80.51 \% \pm 0.51 \%$ 로 농도가 증가함에 따라서 소거능도 농도 의존적인 증가를 보였다. 세포 생 존율 평가(MTT assay)는 농도 $0.25 \mathrm{mg} / \mathrm{mL}$ 에서 $93.33 \% \pm 1.88 \%, 0.5 \mathrm{mg} / \mathrm{mL}$ 에서 $90.66 \% \pm 1.24 \%, 0.75 \mathrm{mg} / \mathrm{mL}$ 에서 $88.66 \% \pm$ $1.69 \%, 0.9 \mathrm{mg} / \mathrm{mL}$ 에서 $83.1 \% \pm 0.94 \%$ 로 나타났다. 0.25 와 $0.5 \mathrm{mg} / \mathrm{mL}$ 의 농도에서 세포 생존율이 $90 \%$ 이상이며 가장 낮은 생 존율도 $80 \%$ 이상으로 세포독성에 대한 안전성에 전혀 문제가 없는 것으로 확인되었다. 항염증 평가에서 농도가 $0.25 \mathrm{mg} / \mathrm{mL}$ 에서 $31.76 \pm 0.52 \mu \mathrm{M}$ 로 감소했으며, $0.5 \mathrm{mg} / \mathrm{mL}$ 일 때 $21.76 \pm 0.52 \mu \mathrm{M}, 0.75 \mathrm{mg} / \mathrm{mL}$ 일 때 $10.86 \pm 0.47 \mu \mathrm{M}, 0.9 \mathrm{mg} / \mathrm{mL}$ 일 때 9.76 $\pm 0.28 \mu \mathrm{M}$ 감소시킨 것으로 나타났다. 세포이동과 회복의 상태를 농도별로 비교한 결과 농도가 $2.5 \mathrm{mg} / \mathrm{mL}, 5 \mathrm{mg} / \mathrm{mL}, 10 \mathrm{mg} /$ $\mathrm{mL}$ 로 높아질수록 빈 공간을 채우는 속도가 활발하며 피부의 회복과 재생에 도움을 줄 수 있는 소재임을 확인하였다. 결론: 인삼열 매박은 생리활성 실험에서 황산화, 항염, 세포 재생의 활성을 갖는 것으로 나타났으며 버려지는 천연 부산물의 재활용을 통해 친환 경적인 천연 성분으로 효과적인 피부개선 화장품 원료로 활용 가능할 것으로 기대된다.

핵심어: 인삼열매박, 피부개선, 항산화, 항염, 피부 재생

\section{참고문헌}

김현숙, 고경숙. 인삼열매 에탄올 추출물의 화장품 소재로서 항산화, 항염 효과. 아시안뷰티화장품학술지, 18: 389-397, 2020.

송지혜, 손명수, 김혜옥, 김종식, 김의수, 김교남. 인삼종자에서 추출한 오일의 항산화 활성. 아시안뷰티화장품학술지, 12 : 239, 2014.

염명훈, 이진영, 김지성, 박찬웅, 김덕희, 김한곤. 인삼열매의 피부노화 억제 효과. 생약학회지, $41: 26-30,2010$.

이가순, 김관후, 성봉재, 김선익, 한승호, 이석수, 양 혜, 유영춘. 인삼열매 추출물의 용매 분획물이 LPS로 유도된 RAW 264.7세포에 대한 항염 활성. 한국약용작물학회지, 22: 455, 2014.

이지현, 조수현, 윤미영, 안성관, 장현희, 이성내, 송규용. 진세노사이드 $\mathrm{Rd}$ 로부터 희귀 진세노사이드의 제조 및 주름개선 효과. 아시안뷰티화장품학술지, 13: 909-916, 2015.

전지민, 최성규, 김윤정, 장수진, 천종우, 이현상. 유산균 발효에 의한 인삼열매 추출물의 항산화•항노화 효과. 대한화장품 학회지, 37: 75-81, 2011.

함하늘, 쉬레스타 아비나쉬 찬드라, 김주은, 이태범, 유병완, 김민숙, 김광상, 차준석, 이용문, 김종엽, 임재윤. 산구절초, 자소엽, 찔레를 함유한 천연 화장품소재의 다성분 동시분석과 항산화활성. 생약학회지, 49: $312-321,2018$. 


\section{中文摘要}

\section{人参浆果渣萃取物改善皮肤的功能}

金賢淑

圆光大学美容设计学科, 全罗北道盆山市, 韩国

目的: 这项研究通过测定人参生理活性来确定人参浆果椬作为美容材料改善皮肤的可性性。方法: 测定人参浆果 椬提取物的总多酚和类黄酮的含量, 通过DPPH自由基清除活性评估抗氧化剂, 以及细胞生存率。为了获得抗 炎作用，测定了NO生成抑制并通过细胞迁移来评估细胞再生。结果：测定结果如下：总多酚含量为335土12.3 $\mathrm{mg} / \mathrm{g}$, 总黄酮含量为 $79 \pm 3.2 \mathrm{mg} / \mathrm{g}$ 。 DPPH自由基清除活性也显示出浓度依赖性的增加, 浓度在 $0.25 \mathrm{mg} /$ $\mathrm{mL}$ 时, 增加到 $37.73 \% \pm 2.47 \%$; 浓度为 $0.5 \mathrm{mg} / \mathrm{mL}$ 时, 增加到 $49.33 \% \pm 0.66 \%$; 浓度为 $0.75 \mathrm{mg} / \mathrm{mL}$ 时, 增 加到 $73.56 \% \pm 3.56 \%$; 浓度为 $0.9 \mathrm{mg} / \mathrm{mL}$ 时, 增加到 $80.51 \% \pm 0.51 \%$ 。细胞生存率（MTT分析）测定结果显 示: 在浓度为 $0.25 \mathrm{mg} / \mathrm{mL}$ 时, 为 $93.33 \% \pm 1.88 \%$ ，在 $0.5 \mathrm{mg} / \mathrm{mL}$ 时，为 $90.66 \% \pm 1.24 \%$; 在 $0.75 \mathrm{mg} / \mathrm{mL}$ 时， 为 $88.66 \% \pm 1.69 \%$; 在 $0.9 \mathrm{mg} / \mathrm{mL}$ 时, 为 $83.1 \% \pm 0.94 \%$ 。在 0.25 和 $0.5 \mathrm{mg} / \mathrm{mL}$ 的浓度下, 细胞存活率大于 $90 \%$, 最低存活率也大于 $80 \%$, 表明细胞毒性的安全性没有问题。抗炎评估显示, 随着浓度的增加, NO降低, 浓度为 $0.25 \mathrm{mg} / \mathrm{mL}$ 时, 减少到 $31.76 \pm 0.52 \mathrm{uM}, 0.5 \mathrm{mg} / \mathrm{mL}$ 时, 减少到 $21.76 \pm 0.52 \mu \mathrm{M}, 0.75 \mathrm{mg} / \mathrm{mL}$ 时, 减少

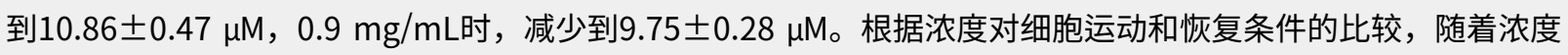
增加到2.5, 5 和 $10 \mathrm{mg} / \mathrm{mL}$ 时, 填充空白空间的速度变得更加活跃, 并且可以确认这是一种有助于皮肤恢复和再 生。结论: 人参浆果椬在生理活性实验中被发现具有抗氧化，消炎和细胞再生的活性，并建议通过回收废弃的天 然植物将其用作有效的皮肤改善化妆品原料。

关键词: 人参浆果椬, 皮肤改善, 抗氧化, 抗炎, 皮肤再生 